\begin{tabular}{cc|c}
\hline Tar. Bil. Der. & Journal of Agricultural Sciences \\
& $\begin{array}{c}\text { Dergi web sayfası: } \\
\text { www.agri.ankara.edu.tr/dergi }\end{array}$ & Journal homepage: \\
& www.agri.ankara.edu.tr/journal
\end{tabular}

\title{
Effects of Heat Stress after Anthesis on PSII Photochemical Efficiency and the Antioxidant Activity of Wheat Cultivars
}

\author{
Mahroo Mojtabaie ZMANI $^{\mathrm{a}}$, Majid NABIPOUR ${ }^{\mathrm{b}}$, Mousa MESKARBASHEE ${ }^{\mathrm{b}}$ \\ ${ }^{a}$ Department of Agriculture, Ramhormoz Branch, Islamic Azad University, Ramhormoz, IRAN

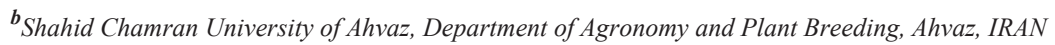

\section{ARTICLE INFO}

Research Article

DOI: 10.15832 /ankutbd.446391

Corresponding Author: Mahroo Mojtabaie ZMANI, E-mail: mahroo.mojtabaei@gmail.com, Tel: +98 (913) 3253451

Received: 05 March 2016, Received in Revised Form: 23 June 2016, Accepted: 29 June 2016

\begin{abstract}
This study was conducted to investigate the effects of heat stress after anthesis on the performance of Photosystem II (PSII) and the enzymatic activity of catalase and ascorbate peroxidase. Two treatments-normal and heat stress-were conducted on four bread wheat cultivars from 7 days after anthesis until maturity. Heat stress led to an acceleration of chlorosis, reduced the efficiency of electron transfer and increased concentrations of malondialdehyde; however, the level of susceptibility varied depending on the cultivars. On the $10^{\text {th }}$ day of heat stress, reductions in fluorescence parameters, depending on the cultivar, were 6.9 to $18.9 \%$ for Fv/Fm, 9 to $21 \%$ for $Ф$ PSII and 8.3 to $19.4 \%$ for F'v/F'm compared to normal conditions. Catalase activity increased after initial exposure to heat stress. However, after 10 days of treatment, catalase activity increased in the Chamran and Aflak cultivars by $32 \%$ and $45 \%$, respectively, but it did not change in the Dez cultivar and decreased 22\% in Darab2. Ascorbate peroxidase activity decreased in two treatments, while the amount of reduction in heat stress treatment was more than the normal treatment. The highest levels of enzymatic activity were observed in Chamran under heat stress conditions, whereas Darab2 and Dez showed the lowest activity of the enzymes. Chlorophyll fluorescence parameters and chlorophyll index had a significant negative correlation with the levels of malondialdehyde; however, they had a significant positive correlation with the antioxidant activity.
\end{abstract}

Keywords: Ascorbate peroxidase; Catalase; Chlorophyll fluorescence; High temperature

\section{Çiçeklenme Sonrası Sıcaklık Stresinin Buğday Çeşitlerinin PSII Fotokimyasal Etkinliği ile Antioksidan Aktivitesine Etkisi}

\section{ESER BILLGISİ}

Araştırma Makalesi

Sorumlu Yazar: Mahroo Mojtabaie ZMANI, E-posta: mahroo.mojtabaei@gmail.com, Tel: +98 (913) 3253451 Geliş Tarihi: 05 Mart 2016, Düzeltmelerin Gelişi: 23 Haziran 2016, Kabul: 29 Haziran 2016

\section{ÖZET}

Bu çalışmanın amacı çiçeklenme sonrası sıcaklık stresinin buğday çeşitlerinin fotosistem II (PSII) ile askorbat peroksidaz ve katalaz enzim aktivitelerine etkisini belirlemektir. Dört ekmeklik buğday çeşidine çiçeklenmeden 7 gün sonar 
başlayıp olgunluğa kadar devam eden sıcaklık stresi uygulanmış, control olarak da sıcaklık stresi uygulanmayan bir grup oluşturulmuştur. Sicaklık stresi klorozun hızlanmasına neden olmuş, elektron taşınım etkinliğini azaltmış ve malondialdehit konsantrasyonunu artırmış ancak duyarlılık düzeyi çeşitlere göre farklılık göstermiştir. Sıcaklık stresinin 10. gününde çeşitlere bağlı olarak floresans parametrelerindeki azalma kontrole göre Fv/Fm için \% 6.9-18.9, ФPSII için \% 9-21 ve F'v/F'm için ise \% 8.3-19.4 arasında değişmiştir. Sıcaklık stresinin başlmasıyla birlikte katalaz aktivitesi artış göstermiştir. Ancak sıcaklık stresi uygulmasından 10 gün sonra katalaz aktivitesi Chamran ve Aflak çeşitlerinde sırasıyla \% 32 ve 45 oranında artmış, Dez çeşidinde değişmemiş ve Darab2 çeşidinde ise \% 22 oranında azalmıştır. Askorbat peroksidaz aktivitesi hem kontrol grubu hem de sıcaklık stresi uygulanan bitkilerde azalmış ancak azalma sıcaklık stresi uygulananlarda daha fazla olmuştur. En yüksek enzimatik aktivite sıcaklık stresi uygulanan Chamran çeşidinde gözlenirken Darab ve Dez çeşitleri en düşük enzim aktivitesine sahip olmuşlardır. Klorofil floresans paramtresi ile klorofil indeksi malondialdehit düzeyleri ile önemli negative korelasyon gösterirken antioksidan aktivitesi ile önemli pozitif korelasyon göstermiştir.

Anahtar Kelimeler: Askorbat peroksidaz; Katalaz; Klorofil floreasns; Yüksek sıcaklık

(C) Ankara Üniversitesi Ziraat Fakültesi

\section{Introduction}

Heat stress during the grain filling period is one of the most important abiotic factors limiting wheat yields (Triticum aestivum L.). Due to the predicted 1.8 to $5.8{ }^{\circ} \mathrm{C}$ increase in global temperature by the end of this century due to global warming (Farooq et al 2011), the importance of this stress is increasing. Heat stress affects many cellular functions. Photosynthesis is one of the physiological processes most sensitive to heat. Under heat stress, decrease in photosynthetic activity leads to reductions in wheat growth (Harding et al 1990). Reduction of photosynthesis at high temperatures occurs due to the impairment of the structure and function of chloroplasts and decrease in chlorophyll content (Xu et al 1995). Several studies have shown that the inhibition of Rubisco activity directly leads to the inhibition of $\mathrm{CO}_{2}$ assimilation under moderate heat stress (Salvucci \& Crafts-Brander 2004), while under severe heat stress, the dissociation of the oxygen evolving complex, inhibition of electron transfer from quinone $\mathrm{A}$ to quinone $\mathrm{B}$ and general damage to the reaction centres of PSII also lead to the inhibition of photosynthesis (Harding et al 1990; Allakhverdiev et al 2008). Heat stress can impair enzyme functions because of the changes in the nature of the enzyme. Degradation of proteins and membranes caused by heat stress leads to an increase in the production of reactive oxygen species (ROS) and this is followed by oxidative stress (Sairam et al 2000). Plants have enzymatic and non-enzymatic refinement systems in order to suppress ROS and eliminate their destructive effects (Farooq et al 2011). Under normal thermal conditions, plants maintain a balance between the production and refinement of ROS. However, heat stress can disrupt this balance (either by increasing the production of activated oxygen species or reducing the quenching ability of ROS in the cell) and reinforce lipid peroxidation of cell membranes (Liu \& Huang 2000; Allakhverdiev et al 2008).

This study was conducted to evaluate the effects of heat stress on the performance of PSII during the grain filling period in four wheat cultivars, each of which have different abilities of tolerating heat stress. Because the antioxidative system in plants can partially prevent oxidative damage, which is caused by the accumulation of electron acceptors and increasing ROS, the antioxidant activity of the four wheat varieties were evaluated.

\section{Material and Methods}

\subsection{Plant material and growth conditions}

Four spring bread wheat cultivars with similar phenology: Aflak (Debeira), Chamran (Attila), Dez (Kauz $\times 2 / O p a t e y / / K a u z)$ and Darab2 (Maya's'/Nac) were used in this experiment. All cultivars have been released by the International Maize and Wheat Improvement Center (CIMMYT) and Chamran is recognised internationally for its ability to tolerate 
heat. The cultivars were sown on November 28, 2011, in pots, $10 \mathrm{~cm}$ in diameter and $50 \mathrm{~cm}$ in height. All pots were kept at an experimental farm at Shahid Chamran University (Ahvaz, Iran) from the time of sowing to 7 days after anthesis. A total of 45 pots of each cultivar was sown for each replication. Each pot was filled with a mixture of loam soil (with $0.82 \%$ organic material) and 12 grams of rotten manure before planting. $\mathrm{N}, \mathrm{P}$ and $\mathrm{K}$ were added to each pot; $36.8 \mathrm{mg} \mathrm{N}$ in the form of urea, $36.8 \mathrm{mg}$ $\mathrm{P}$ in the form of triple superphosphate and $20 \mathrm{mg}$ $\mathrm{K}$ in the form of potassium sulphate. Five seeds were sown in each pot and after three weeks, three seedlings were maintained per pot. At the end of tillering, stem elongation and also at the beginning of spike emergence, $36.8 \mathrm{mg} \mathrm{N}$ as urea was added to each pot. All pots were irrigated after every two days and as needed to avoid any water stress.

At 7 days after anthesis-defined as anthers extruded from $50 \%$ of main culm inflorescences-all pots of each cultivar were randomly divided into two groups and were transferred to two separate phytotrons with different thermal conditions and were kept there until maturity. One phytotron was maintained under normal temperature conditions; daytime temperatures were set at $25{ }^{\circ} \mathrm{C}$ for $4 \mathrm{~h}, 21^{\circ} \mathrm{C}$ for $5 \mathrm{~h}$ before and after the $4 \mathrm{~h}$ period and $16{ }^{\circ} \mathrm{C}$ at night time for 10 $\mathrm{h}$. The other phytotron was maintained under hotter conditions; daytime temperatures were set at $37{ }^{\circ} \mathrm{C}$ for $4 \mathrm{~h}, 31^{\circ} \mathrm{C}$ for $5 \mathrm{~h}$ before and after the $4 \mathrm{~h}$ period and $25^{\circ} \mathrm{C}$ at night time for $10 \mathrm{~h}$. In both phytotrons, the relative humidity ranged between 50 and $70 \%$, the photosynthetic photon flux density was set at 650 $\mu \mathrm{mol} \mathrm{m} \mathrm{m}^{-2} \mathrm{~s}^{-1}$ at $10 \mathrm{~cm}$ above the plant spikes.

\subsection{Measurements of chlorophyll fluorescence and SPAD values}

Five main stems were selected among the tagged main stems (several main stems of similar age were tagged at the time of anthesis in each cultivar) and flag leaves of these stems were used for measuring parameters of chlorophyll fluorescence and SPAD values in both phytotrons. The fluorescence metre (Walz, Germany) was used for measuring these parameters (Fo, Fm, Ft, F'm) at 4, 7 and 10 days after temperature treatments. Fv/Fm, ФPSII and F'v/F'm were calculated using equations 1 through 4 (Baker \& Rosenqvist 2004).

$F v / F m=(F m-F o) / F m$

$\emptyset P S I I=\left(F^{\prime} m-F t\right) / F^{\prime} m$

$F^{\prime} O=\frac{F o}{\left(\frac{F v}{F m}\right)+\left(\frac{F o}{F^{\prime} m}\right)}$

$F^{\prime} v / F^{\prime} m=\left(F^{\prime} m-F^{\prime} o\right) / F^{\prime} m$

SPAD values of flag leaves were also measured at five-day intervals from 7 days after anthesis until the time of leaf yellowing by using a chlorophyll metre (Minolta Chlorophyll Meter SPAD-502).

\subsection{Estimation of antioxidant enzymatic activity and malondialdehyde (MDA) concentrations}

Three flag leaves from main stems of similar ages were sampled at four stages: $0,4,7$ and 10 days after temperature treatments. Potassium phosphate extraction buffer $(50 \mathrm{mM}$ containing $1.0 \mathrm{mM}$ EDTA, $\mathrm{pH}$ 7) was used to extract catalase (CAT), while ascorbate peroxidase (APX) was extracted using 50 $\mathrm{mM}$ potassium phosphate buffer $(\mathrm{pH} 7)$ containing $1.0 \mathrm{mM}$ EDTA and $2 \mathrm{mM}$ ascorbate (Almeselmani et al 2006). Each enzyme extract was prepared by first grinding $0.5 \mathrm{~g}$ leaf sample with liquid nitrogen and then with extraction buffer. Extracts were centrifuged at $10,000 \times g$ at $2{ }^{\circ} \mathrm{C}$ for $20 \mathrm{~min}$. The supernatant was used to measure levels of enzyme activity.

CAT activity was assayed according to Beers $\&$ Sizer (1952). The reaction mixture $(3 \mathrm{~mL})$ contained $50 \mathrm{mM}$ potassium phosphate buffer $(\mathrm{pH}$ 7), $15 \mathrm{mM} \mathrm{H}_{2} \mathrm{O}_{2}$ and $100 \mu \mathrm{L}$ of enzyme extract. Each unit of CAT activity was determined by calculated the breakdown of $\mathrm{H}_{2} \mathrm{O}_{2}(\mathrm{mM})$ per minute by measuring the absorbance change at $240 \mathrm{~nm}$ and using the extinction coefficient of $39.4 \mathrm{M}^{-1} \mathrm{~cm}^{-1}$. APX activity was assayed according to Nakano \& Asada (1981). The reaction mixture $(3 \mathrm{~mL})$ contained $50 \mathrm{mM}$ potassium phosphate buffer $(\mathrm{pH}$ 7), $0.3 \mathrm{mM}$ ascorbate, $0.07 \mathrm{mM}$ EDTA, $0.1 \mathrm{mM}$ $\mathrm{H}_{2} \mathrm{O}_{2}$ and $100 \mu \mathrm{L}$ of enzyme extract. Each unit of APX activity was calculated by quantifying the amount of oxidized ascorbate $(\mu \mathrm{M})$ per minute by 
measuring the reduction of absorbance at $290 \mathrm{~nm}$ and using the extinction coefficient of $2.8 \mathrm{mM}^{-1}$ $\mathrm{cm}^{-1}$. Lipid peroxidation was assayed according to Heath \& Packer (1969) by monitoring the formation of malionaldehyde-thiobarbituric. Concentrations of accumulated MDA were calculated by using an absorption coefficient of $155 \mathrm{mM}^{-1} \mathrm{~cm}^{-1}$ and were expressed as $\mu \mathrm{M}$ per $\mathrm{g}$ of fresh weight.

\subsection{Statistical analysis}

The experiment was arranged in a completely randomized block design with three replicates in each phytotron. A combined analysis of variance was performed using GLM procedures across two phytotrons and genotypes for each measured trait. Also, comparisons of means were performed by Fisher's protected least significant difference at $5 \%$ probability. Associations between traits were examined by correlation analysis when appropriate.

\section{Results and Discussion}

\subsection{Grain yield and its components}

Heat stress significantly reduced the grain yields of the main spike. Maximum reductions in grain yield were observed in the Darab2 and Aflak cultivars, while the least amount of reductions in yields was observed in Dez and Chamran (Table 1). Under heat stress conditions, single grain weights decreased an average $34.4 \%$. The largest percentage of grain weight reduction was observed in Darab2 (41.12\%) whereas Dez had the lowest grain weight reduction $(27.26 \%)$ among cultivars. Heat stress led to a significant reduction in the grain number per main spike (from 1.99 to $5.10 \%$, depending on the cultivars) (Table 1). This indicates that the observed decline in main spike grain yields can mostly be attributed to the reduction in grain weights as has been observed in other studies (Tahir \& Nakata 2005; Zamani et al 2014). The decrease in sink strength (either through reducing the number of endosperm cells (Feng et al 2000) or by reducing metabolic activity, which leads to the synthesis of starch in the grain (Keeling et al 1993)) and decrease in duration of starch accumulation in the grain (Hurkman et al 2003) can explain the sharp decline in grain weight under heat stress conditions. In this experiment, heat stress led to a significant reduction (on an average of $36.6 \%)$ in the grain filling duration of all cultivars (Table 2). The grain filling rate of Darab2 decreased

Table 1- Main spike grain yield and components in wheat cultivars grown under normal and heat stress temperature treatments and reduction (percent) yield under heat stress

\begin{tabular}{|c|c|c|c|c|c|c|c|}
\hline \multirow[t]{2}{*}{ Cultivar } & \multicolumn{3}{|c|}{$\begin{array}{l}\text { Grain yield } \\
\left(g \text { main spike }{ }^{-1}\right)\end{array}$} & \multicolumn{2}{|c|}{$\begin{array}{l}\text { Grain number } \\
\text { (per main spike) }\end{array}$} & \multicolumn{2}{|c|}{$\begin{array}{l}\text { Single grain weight } \\
(\mathrm{mg})\end{array}$} \\
\hline & $N \dagger$ & $H \dagger$ & $R \xi(\%)$ & $N$ & $H$ & $N$ & $H$ \\
\hline Chamran & $1.27 \mathrm{~b}$ & $0.94 \mathrm{bc}$ & $26.36 \mathrm{~b}$ & $48.58 \mathrm{c}$ & $46.61 \mathrm{c}$ & $28.66 \mathrm{~b}$ & $19.80 \mathrm{a}$ \\
\hline Aflak & $1.29 \mathrm{~b}$ & $0.86 \mathrm{c}$ & $33.09 \mathrm{a}$ & $50.81 \mathrm{c}$ & $48.19 \mathrm{c}$ & $30.01 \mathrm{~b}$ & $18.49 \mathrm{a}$ \\
\hline Dez & $1.32 \mathrm{~b}$ & $1.03 \mathrm{a}$ & $21.96 \mathrm{~b}$ & $61.20 \mathrm{a}$ & $59.97 \mathrm{a}$ & $24.65 \mathrm{c}$ & $17.93 \mathrm{a}$ \\
\hline Darab2 & $1.55 \mathrm{a}$ & $1.00 \mathrm{ab}$ & $35.22 \mathrm{a}$ & $56.82 \mathrm{~b}$ & $54.05 \mathrm{~b}$ & $33.49 \mathrm{a}$ & $19.72 \mathrm{a}$ \\
\hline Mean & 1.36 & 0.96 & 29.16 & 54.35 & 52.21 & 29.20 & 18.98 \\
\hline \multicolumn{8}{|c|}{ Analysis of variance } \\
\hline $\mathrm{T} \boldsymbol{9}$ & $* *$ & & & $* *$ & & $* *$ & \\
\hline $\mathrm{G} \#$ & $* *$ & & & $* *$ & & $* *$ & \\
\hline $\mathrm{T} \times \mathrm{G}$ & $* *$ & & & ns & & $* *$ & \\
\hline
\end{tabular}

$\uparrow$, normal conditions; + , heat stress conditions; $\S$, reduction (percent) because of heat stress; $\uparrow$, temperature treatment; \#, genotype; ns and $* *$, non-significant and significant at $1 \%$ probability levels, respectively; means, followed by similar letter are not significantly different $(\mathrm{P}<0.05)$ according to LSD test 
$12 \%$ as a result of heat stress while that of Dez and Aflak increased $18 \%$ and $8 \%$, respectively. There was no change in the grain filling rate observed in Chamran (Table 2). These results indicate that the reduction in grain filling duration (decrease in duration of starch accumulation in the grain) played an important role in the reduction in grain weight of all cultivars. In addition, the sharp decline in grain weight of Darab2 may be attributed to the reduction of grain filling rate as well as grain filling duration in this cultivar. Other reasons of reduction in grain weight under heat stress conditions include the impacts of heat stress on the photosynthetic system (Either through damage to PSII or by inhibiting of the activity of Rubisco activase) (Allakhverdiev et al 2008).

Table 2- Grain filling rate and duration in wheat cultivars grown under normal and heat stress temperature treatments

\begin{tabular}{lllll}
\hline \multirow{2}{*}{ Cultivar } & \multicolumn{2}{l}{$\begin{array}{l}\text { Grain filling rate } \\
\left({\text { (mg } \text { grain }^{-1} \text { day }}^{-1}\right)\end{array}$} & \multicolumn{2}{l}{$\begin{array}{l}\text { Grain filling duration } \\
\text { (day })\end{array}$} \\
\cline { 2 - 5 } & $N+$ & $H \neq$ & $N$ & $H$ \\
\hline Chamran & $1.09 \mathrm{~b}$ & $1.09 \mathrm{~b}$ & 26.55 & 18.17 \\
Aflak & $1.08 \mathrm{~b}$ & $1.17 \mathrm{ab}$ & 27.98 & 15.85 \\
Dez & $0.90 \mathrm{a}$ & $1.06 \mathrm{~b}$ & 27.46 & 16.96 \\
Darab2 & $1.37 \mathrm{a}$ & $1.21 \mathrm{a}$ & 24.64 & 16.56 \\
\hline Mean & 1.11 & 1.13 & 26.66 & 16.89 \\
\hline & & & & \\
\hline $\mathrm{T}$ ब & $\mathrm{ns}$ & & $* *$ & \\
$\mathrm{G} \#$ & $* *$ & & $\mathrm{~ns}$ & \\
$\mathrm{~T} \times \mathrm{G}$ & $* *$ & & $\mathrm{~ns}$ & \\
\hline
\end{tabular}

$\dagger$, normal conditions; $\$$, heat stress conditions; $\boldsymbol{q}$, temperature treatment; \#, genotype; ns and **, non-significant and significant at $1 \%$ probability levels, respectively; Means, followed by similar letter are not significantly different $(\mathrm{P}<0.05)$ according to LSD test

\subsection{Chlorophyll fluorescence and SPAD values}

Heat stress led to a significant decrease in $\mathrm{Fv} / \mathrm{Fm}$, ФPSII and F'v/F'm at 4, 7 and 10 days after exposure to high temperatures $(\mathrm{P}<0.01)$. The observed decline in $\mathrm{Fv} / \mathrm{Fm}$ on the $7^{\text {th }}$ day of heat stress varied from $3.3 \%$ in Chamran to 7\% in Dez. The highest percentage of decline in ФPSII was observed in Darab2 and Dez cultivars as $6.7 \%$ and $6.2 \%$, respectively. The observed decline in F'v/F'm also varied from $2.8 \%$ in Chamran to $6.9 \%$ in Dez (Figure 1). Over time and under prolonged periods of stress 10 days after exposure to high temperatures, reductions in fluorescence values, depending on the cultivar, were 6.9 to $18.9 \%$ for $\mathrm{Fv} /$ Fm, 9 to $21 \%$ for $\Phi$ PSII and 8.3 to $19.4 \%$ for F'v/F'm compared to cultivars exposed to normal conditions. The lowest reduction in fluorescence was observed in Chamran, while the highest percentage was observed in Darab2 (Figure 1).
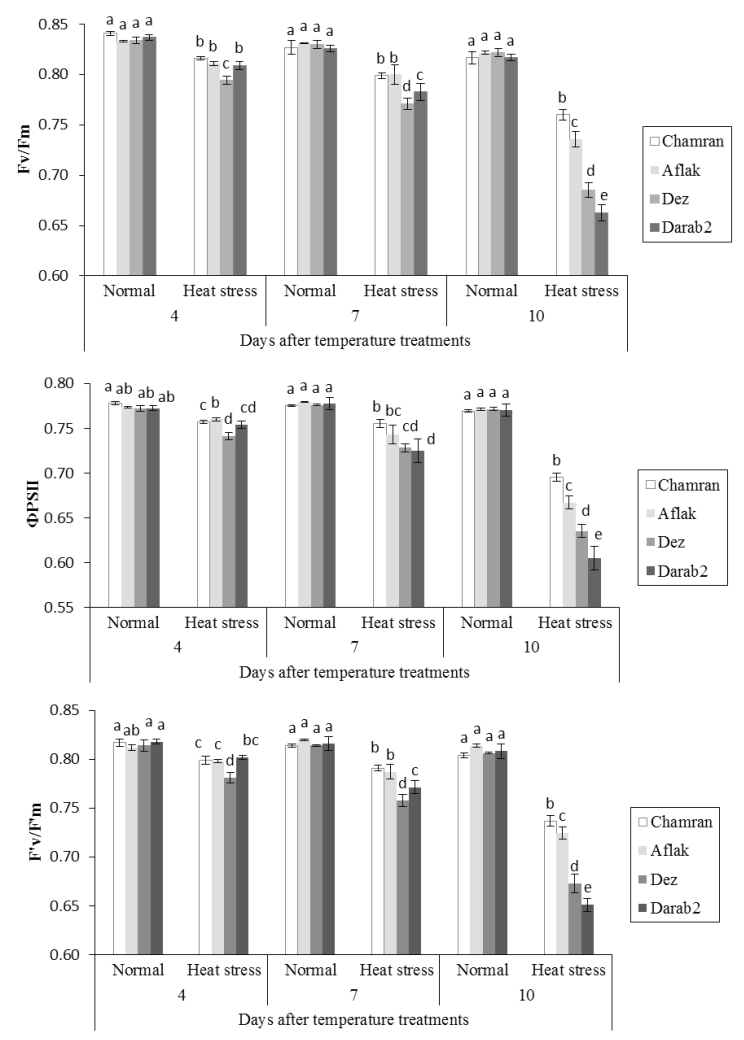

Figure 1- Changes of $F_{v} / F_{m}$, TPSII and $F_{v} / F_{m}$ in flag leaves of wheat cultivars under normal and heat stress temperature treatments. The bars superscripted by different letters within the same "days after temperature treatments" are significantly different $(\mathrm{P}<0.05)$ according to LSD test 
ФPSII is an estimation of the quantum efficiency of linear electron transport through PSII and is an indicator of the amount of absorbed energy used in photochemical activity. Reduction in this parameter indicates a reduction in electron linear transmission in PSII and the slowing the flow of electrons due to a delay in the redox potential in the primary quinone acceptor of PSII (QA). F'v/F'm is also an estimation of the maximum photochemical efficiency of PSII at the given light intensity and reveals the efficiency of PSII when all reaction centres are open (Maxwell \& Johnson 2000; Baker \& Rosenqvist 2004). The reduction in ФPSII and F'v/F'm under moderate heat stress is mainly associated with an increase in non-photochemical quenching (NPQ) of energy in the form of heat loss and is considered a mechanism of photoprotection. Due to an increase in NPQ and protection from photoinhibition, PSII centres remain intact under these conditions and $\mathrm{Fv} / \mathrm{Fm}$ will not change (Maxwell \& Johnson 2000; Zamani et al 2015). NPQ cannot remove excess excited electron energy under intense heat stress or prolonged exposure to heat stress. Therefore, photoinhibition damage occurs in PSII and Fv/Fm decreases (Dias et al 2011; Zamani et al 2015). In this study, a reduction in $\mathrm{Fv} / \mathrm{Fm}$, ФPSII, and F'v/F'm under heat stress revealed that an important component of the reaction centres in PSII had been damaged. With an increase in the duration of heat stress, high temperatures accelerate the disruption of thylakoid components, separate light-harvesting pigments from the reaction centres of PSII and also accelerate the degradation of chlorophyll that is similar to conditions brought about by the ageing of plants (Harding et al 1990).

We observed a strong relationship between values of chlorophyll fluorescence and the relative content of chlorophyll (SPAD value) in the flag leaves (Table 4); this confirms the occurrence of disruption in chloroplasts, leaf damage and premature ageing under heat stress conditions. A reduction in chlorophyll content and chlorophyll fluorescence leads to a reduction in the photosynthetic capacity of the plant (Xu et al 1995). Plant yields decline if a plant fails to use alternative sources (stem reserves) to compensate for the reduction in photosynthetic capacity (Tahir \& Nakata 2005). Chlorosis started earlier in Darab2 and Dez and these cultivars had the lowest chlorophyll index on the $10^{\text {th }}$ day of heat stress. The evaluated parameters of chlorophyll fluorescence in these Darab2 and Dez were also low. Darab2 had the lowest values of Fv/Fm, ФPSII and F'v/F'm and the highest reductions in these parameters under heat stress conditions combined with the highest reductions in grain yield. These observations confirm this cultivar is sensitive to heat stress. Despite a sharp decline of photosynthetic capacity in Dez, Dez is able to use its stem reserves for grain growth (Zamani et al 2014). Dez had the lowest reductions in grain yields under heat stress and can be classified as a semi-tolerant cultivar to heat stress.

\subsection{Antioxidant enzymatic activity and $M D A$ concentrations}

Heat stress led to a significant increase in CAT activity at 4 and 7 days after temperature treatments. These increases ranged from $11 \%$ in Dez to $38 \%$ in Chamran on the $4^{\text {th }}$ day of heat stress and $12 \%$ in Darab2 to $42 \%$ in Aflak on the $7^{\text {th }}$ day of heat stress (Table 3). CAT activity in Aflak and Chamran was higher under stress conditions than normal conditions on the $10^{\text {th }}$ day by $32 \%$ and $45 \%$, respectively, while no changes in its activity were observed in Dez and it decreased in Darab2 by $22 \%$.

An increase in CAT activity is related to an increase in stress tolerance (Sairam et al 2000). Increased CAT activity has been reported by Almeselmani et al (2006) in other tolerant wheat cultivars under heat stress conditions. Zhao et al (2007) reported that under heat stress conditions $\left(34{ }^{\circ} \mathrm{C} / 22{ }^{\circ} \mathrm{C}\right.$ from 7 DAA to maturity), CAT activity was higher than normal conditions until 14 days after anthesis while its activity decreased after that period.

There was no significant difference in APX activity between the two temperature treatments until the $7^{\text {th }}$ day of the experiment (Table 3). Over time, APX activity decreased in both thermal treatments. APX activity in Dez and Darab2 on the $10^{\text {th }}$ day of heat stress decreased more than when under normal conditions by $27 \%$ and $24 \%$, respectively. 
Table 3- Antioxidant enzymes (CAT and APX) activity and MDA concentration in flag leaves of wheat cultivars under normal and heat stress temperature treatments

\begin{tabular}{|c|c|c|c|c|c|c|}
\hline \multicolumn{7}{|c|}{ CAT activity ( $\mu \mathrm{mol} \mathrm{H}_{2} \mathrm{O}_{2}$ dec $\mathrm{min}^{-1} \mathrm{mg}^{-1}$ protein) } \\
\hline \multirow{2}{*}{ Cultivar } & \multicolumn{2}{|c|}{$4 D A T$} & \multicolumn{2}{|c|}{$7 D A T$} & \multicolumn{2}{|c|}{$10 \mathrm{DAT}$} \\
\hline & $N+$ & $H \neq$ & $N$ & $H$ & $N$ & $H$ \\
\hline Chamran & $145.43 \mathrm{a}$ & $191.77 \mathrm{a}$ & 121.83 & 166.87 & $110.13 \mathrm{a}$ & $146.93 \mathrm{a}$ \\
\hline Aflak & $125.10 \mathrm{~b}$ & $173.03 \mathrm{ab}$ & 112.13 & 159.13 & $84.20 \mathrm{~b}$ & $121.70 \mathrm{a}$ \\
\hline Dez & $141.60 \mathrm{ab}$ & $157.43 \mathrm{~b}$ & 124.17 & 143.27 & $100.33 \mathrm{ab}$ & $92.50 \mathrm{~b}$ \\
\hline Darab2 & $129.30 \mathrm{ab}$ & $157.50 \mathrm{~b}$ & 127.70 & 143.53 & $111.50 \mathrm{a}$ & $86.50 \mathrm{~b}$ \\
\hline Mean & 135.36 & 169.93 & 121.46 & 153.20 & 101.54 & 111.91 \\
\hline \multicolumn{7}{|c|}{ Analysis of variance } \\
\hline $\mathrm{T} \Phi$ & $*$ & & \multicolumn{2}{|l|}{$* *$} & \multicolumn{2}{|l|}{ ns } \\
\hline G\# & $* *$ & & \multicolumn{2}{|l|}{ ns } & \multicolumn{2}{|l|}{$* *$} \\
\hline $\mathrm{T} \times \mathrm{G}$ & ns & & \multicolumn{2}{|l|}{$*$} & \multicolumn{2}{|l|}{$* *$} \\
\hline \multicolumn{7}{|c|}{ APX activity (nmol ascorbate dec $\mathrm{min}^{-1} \mathrm{mg}^{-1}$ protein) } \\
\hline \multirow{2}{*}{ Cultivar } & \multicolumn{2}{|c|}{$4 D A T$} & \multicolumn{2}{|c|}{$7 D A T$} & \multicolumn{2}{|c|}{$10 D A T$} \\
\hline & $N$ & $H$ & $N$ & $H$ & $N$ & $H$ \\
\hline Chamran & $257.37 \mathrm{a}$ & $277.57 \mathrm{a}$ & 225.87 & 225.43 & $213.33 \mathrm{a}$ & $193.67 \mathrm{a}$ \\
\hline Aflak & $188.00 \mathrm{c}$ & $210.43 \mathrm{c}$ & 239.30 & 179.73 & $177.23 \mathrm{~b}$ & $160.77 \mathrm{~b}$ \\
\hline Dez & $228.47 \mathrm{~b}$ & $242.20 \mathrm{~b}$ & 213.57 & 227.53 & $191.20 \mathrm{~b}$ & $139.60 \mathrm{c}$ \\
\hline Darab2 & $229.07 \mathrm{~b}$ & $241.57 \mathrm{~b}$ & 223.23 & 212.27 & $173.97 \mathrm{~b}$ & $132.47 \mathrm{c}$ \\
\hline Mean & 225.73 & 242.94 & 225.49 & 211.24 & 188.93 & 156.63 \\
\hline \multicolumn{7}{|c|}{ Analysis of variance } \\
\hline $\mathrm{T}$ & ns & & \multicolumn{2}{|l|}{ ns } & \multicolumn{2}{|l|}{$* *$} \\
\hline $\mathrm{G}$ & $* *$ & & \multicolumn{2}{|l|}{ ns } & \multicolumn{2}{|l|}{$* *$} \\
\hline $\mathrm{T} \times \mathrm{G}$ & ns & & \multicolumn{2}{|l|}{$*$} & \multicolumn{2}{|l|}{$*$} \\
\hline \multicolumn{7}{|c|}{ MDA concentration $\left(\mu \mathrm{mol} \mathrm{g}^{-1} \mathrm{FW}\right)$} \\
\hline \multirow{2}{*}{ Cultivar } & \multicolumn{2}{|c|}{$4 D A T$} & \multicolumn{2}{|c|}{$7 D A T$} & & AT \\
\hline & $N$ & $H$ & $N$ & $H$ & $N$ & $H$ \\
\hline Chamran & $1.50 \mathrm{~b}$ & $1.57 \mathrm{~b}$ & $1.55 \mathrm{a}$ & $1.78 \mathrm{c}$ & $1.91 \mathrm{a}$ & $2.34 \mathrm{c}$ \\
\hline Aflak & $1.71 \mathrm{a}$ & $1.80 \mathrm{a}$ & $1.74 \mathrm{a}$ & $1.89 \mathrm{bc}$ & $2.02 \mathrm{a}$ & $2.53 \mathrm{c}$ \\
\hline Dez & $1.50 \mathrm{~b}$ & $1.88 \mathrm{a}$ & $1.55 \mathrm{a}$ & $2.05 \mathrm{ab}$ & $1.94 \mathrm{a}$ & $2.89 \mathrm{~b}$ \\
\hline Darab2 & $1.72 \mathrm{a}$ & $1.94 \mathrm{a}$ & $1.54 \mathrm{a}$ & $2.17 \mathrm{a}$ & $2.00 \mathrm{a}$ & $3.21 \mathrm{a}$ \\
\hline Mean & 1.61 & 1.79 & 1.60 & 1.97 & 1.97 & 2.74 \\
\hline Analysis & ariance & & & & & \\
\hline $\mathrm{T}$ & $*$ & & $* *$ & & $* *$ & \\
\hline G & $*$ & & $*$ & & $* *$ & \\
\hline $\mathrm{T} \times \mathrm{G}$ & ns & & $*$ & & $* *$ & \\
\hline
\end{tabular}

$\dagger$, normal conditions; + , heat stress conditions; 9 , temperature treatment; $\#$, genotype; ns, $*$ and $* *$, non-significant, significant at $5 \%$ and $1 \%$ probability levels, respectively; DAT, days after temperature treatments; Means, followed by similar letter are not significantly different $(\mathrm{P}<0.05)$ according to LSD test

Although, under heat stress, a reduction in APX activity was also observed in Chamran and Aflak but the difference between the two treatments was not significant (Table 3).
The observed decline in APX activity over the time was likely due to the oxidative degradation of protein molecules as a result of cellular ageing and increase in stress duration (Sairam et al 2000). 
CAT and APX are two key enzymes in the activeoxygen scavenging system that can suppress the production of ROS (Zhao et al 2007). Kumar et al (2011) evaluated the isoenzymic profile of APX under a heat shock treatment in two tolerant and sensitive cultivars of wheat. They observed that the transcription levels and the number of different isoenzymes play very important roles in the removal of hydrogen peroxide and provide tolerance to thermal stress.

In this study, heat stress led to an increase in MDA, which is an indicator of peroxidation of phospholipids and unsaturated fatty acids. These increases ranged from $4 \%$ in Chamran and Aflak to $25 \%$ in Dez on the $4^{\text {th }}$ day of heat stress and $8 \%$ in Aflak to $41 \%$ in Darab2 on the $7^{\text {th }}$ day of heat stress. When the duration of heat stress was extended beyond 10 days, MDA concentrations increased from 23\% in Chamran to $61 \%$ in Darab2 under heat stress conditions (Table 3 ).

With a reduction in efficiency of electron transfer in PSII and accumulation of reduced electron acceptors, oxygen acts as an alternative acceptor of electrons and the peroxidation of membrane fatty acids increases. A significant negative correlation between chlorophyll fluorescence parameters (indicators for the efficiency of PSII electron transfer) and the levels of MDA (Table 4) also represents an increase in the lipid peroxidation of the thylakoid membrane due to a reduction of PSII electron transport activity. Powerful antioxidant systems can partially control the production of toxic oxygen radicals and also balance the production and refining of these radicals. When the activities of antioxidants are reduced in plant tissues under heat stress conditions, the balance between ROS production and refining is disturbed and the peroxidation of unsaturated fatty acids of cell membranes increases (Liu \& Huang 2000). This is corroborated by results obtained in this study; there was a significant negative correlation between MDA concentrations and activities of CAT and APX (Table 4). The negative relationship between MDA concentrations and activities of antioxidant enzymes, including CAT and APX, has been also reported by Asthir et al (2009). A significant negative correlation between the relative content of chlorophyll (SPAD value) and MDA concentrations of the flag leaves (Table 4) also demonstrates that the lipid peroxidation of membranes caused by ROS leads to the degradation of chlorophyll (chlorosis). Liu \& Huang (2000) stated that reduced cell membrane stability, chlorophyll degradation and leaf senescence result from the lipid peroxidation of membranes caused by ROS. The significant positive correlation between the SPAD value and antioxidant activity observed in this study (Table 4) may also confirm the effect of ROS on chlorophyll degradation and acceleration of the ageing process.

Table 4- Correlation coefficient between chlorophyll fluorescence parameters, CAT activity, APX activity, MDA concentration and SPAD value under heat stress conditions on 7 and $\mathbf{1 0}$ days after temperature treatments in four wheat cultivars

\begin{tabular}{|c|c|c|c|c|c|c|}
\hline & $F v / F m$ & ФPSII & $F^{\prime} v / F^{\prime} m$ & $M D A$ & $C A T$ & $A P X$ \\
\hline ФPSII & $0.97^{* * *}$ & & & & & \\
\hline $\mathrm{F}^{\prime} \mathrm{v} / \mathrm{F}^{\prime} \mathrm{m}$ & $0.99^{* * * *}$ & $0.96^{* * *}$ & & & & \\
\hline MDA & $-0.95^{* * *}$ & $-0.97^{* * *}$ & $-0.94^{* * *}$ & & & \\
\hline CAT & $0.92^{* * * *}$ & $0.91^{* * *}$ & $0.91^{* * *}$ & $-0.94^{* * * *}$ & & \\
\hline APX & $0.70^{* *}$ & $0.77^{* * * *}$ & $0.67^{* *}$ & $-0.75^{* * *}$ & $0.65^{* *}$ & \\
\hline $\begin{array}{l}\text { SPAD } \\
\text { value }\end{array}$ & $0.82^{* * *}$ & $0.83^{* * *}$ & $0.80^{* * *}$ & $-0.82^{* * *}$ & $0.83^{* * *}$ & $0.69^{* *}$ \\
\hline
\end{tabular}

\section{Conclusions}

According to our results, the Chamran cultivar is semi-tolerant to heat stress; it demonstrated the lowest levels of MDA in all stages of this experiment and exhibited the highest activities of CAT and APX. It seems that an increase in CAT activity under heat stress in Chamran along with its higher activity of APX compared to the other cultivars, has been effective in combating heat stress. In Darab2 (which had the largest decreases in grain yield under heat stress conditions), the activities of APX and CAT decreased. The increase in MDA concentrations under heat stress confirms the sensitivity of Darab2 to hotter conditions. Dez is also semi-tolerant to 
heat stress. There was a minimum reduction in yields of Dez under heat stress conditions, while the activities of CAT and APX were low in this cultivar. Reduction in electron transfer efficiency and the relative content of chlorophyll under hot conditions; as an indicator of damages to the photosynthetic system under heat stress, were also observed in this cultivar. Dez is probably able to compensate for a reduction in photosynthetic activity by using stem reserves and transferring those resources to growing grain (Zamani et al 2014). Also, an increase of the grain filling rate is contributed to the prevention of a sharp decline of grain weight in this cultivar.

It can be concluded that, in some cultivars tolerance to heat is related to the levels of antioxidant enzymatic activity. Heat-tolerant genotypes likely have more efficient refinement systems compared to sensitive genotypes.

\begin{tabular}{|ll|}
\hline Abbreviations and Symbols \\
\hline PSII & Photosystem II \\
QA & Primary quinone electron acceptor of PSII \\
Fv/Fm & $\begin{array}{l}\text { Maximum quantum efficiency of PSII un- } \\
\text { der given dark conditions }\end{array}$ \\
TPSII & $\begin{array}{l}\text { Quantum efficiency of PSII under given } \\
\text { light conditions }\end{array}$ \\
F'v/F'm $^{\prime}$ & $\begin{array}{l}\text { Maximum quantum efficiency of PSII un- } \\
\text { der given light conditions }\end{array}$ \\
NPQ & Non-photochemical quenching \\
CAT & Catalase \\
APX & Ascorbate peroxidase \\
MDA & Malondialdehyde \\
DAA & Days after anthesis \\
ROS & Reactive oxygen species \\
\hline
\end{tabular}

\section{References}

Allakhverdiev S I, Kreslavski V D, Klimov V V, Los D A, Carpentier R \& Mohanty P (2008). Heat stress: An overview of molecular responses in photosynthesis. Photosynthesis Research 98: 541-550

Almeselmani M, Deshmukh P S, Sairam R K, Kushwaha S R \& Singh T P (2006). Protective role of antioxidant enzymes under high temperature stress. Plant Science 171: $382-388$
Asthir B, Kaur S \& Mann S K (2009). Effect of salicylic and abscisic acid administered through detached tillers on antioxidant system in developing wheat grains under heat stress. Acta Physiologiae Plantarum 31: 1091-1096

Baker N R \& Rosenqvist E (2004). Applications of chlorophyll fluorescence can improve crop production strategies: an examination of future possibilities. Journal of Experimental Botany 55(403): 1607-1621

Beers R F \& Sizer I (1952). A spectrophotometric method for measuring the breakdown of hydrogen by catalase. Journal of Biochemistry 195: 133-140

Dias A S, Semedo J, Ramalho J C \& Lidon F C (2011). Bread and durum wheat under heat stress: A comparative study on the photosynthetic performance. Journal of Agronomy and Crop Science 197: 50-56

Farooq M, Bramley H, Palta J A \& Siddique H M (2011). Heat stress in wheat during reproductive and grainfilling phases. Critical Reviews in Plant Sciences 30: $1-17$

Feng C N, Guo W S, Shi J S, Peng Y X \& Zhu X K (2000). Effect of high temperature after anthesis on endosperm cell development and grain weight in wheat. Acta Agronomica Sinica 26: 399-405

Harding S A, Guikema J A \& Paulsen G M (1990). Photosynthetic decline from high temperature stress during maturation of wheat. I. Interaction with senescence processes. Plant Physiology 92: 648-653

Heath R L \& Packer L (1969). Photoperoxidation in isolated chloroplast. I. Kinetics and stoichiometry of fatty acid peroxidation. Archives of Biochemistry and Biophysics 125: 189-198

Hurkman W J, McCue K F, Altenbach S B, Korn A, Tanaka C K, Kothari K M, Johnson E L, Bechtel D B, Wilson J D, Anderson O D \& DuPont F M (2003). Effect of temperature on expression of genes encoding enzymes for starch biosynthesis in developing wheat endosperm. Plant Science 164: 873-881

Keeling P L, Bacon P J \& Holt D C (1993). Elevated temperature reduces starch deposition in wheat endosperm by reducing the activity of soluble starch synthase. Planta 191: 342-348

Kumar R R, Goswami S, Kumar N, Pandey S K, Pandey V C, Sharma S K, Pathak H \& Rai R.D (2011). Expression of novel ascorbate peroxidase isoenzymes of wheat (Triticum aestivum L.) in response to heat stress. International Journal of Plant Physiology and Biochemistry 3(11): 188-194 
Liu X \& Huang B (2000). Heat stress injury in relation to membrane lipid peroxidation in creeping bentgrass. Crop Science 40: 503-510

Maxwell K \& Johnson G N (2000). Chlorophyll fluorescence-a practical guide. Journal of Experimental Botany 51(345): 659-668

Nakano Y \& Asada K (1981). Hydrogen peroxidase is scavenged by ascorbate-specific peroxidase in spinach chloroplasts. Plant Cell Physiology 22: 867-880

Sairam R K, Srivastava G C \& Saxena D C (2000). Increased antioxidant activity under elevated temperature: a mechanism of heat stress tolerance in wheat genotypes. Biologia Plantarum 43(2): 245-251

Salvucci M E \& Crafts-Brandner S J (2004). Relationship between the heat tolerance of photosynthesis and the thermal stability of Rubisco activase in plants from contrasting thermal environments. Plant Physiology 134: $1460-1470$

Tahir I S A \& Nakata N (2005). Remobilization of nitrogen and carbohydrate from stems of bread wheat in response to heat stress during grain filling. Journal of Agronomy and Crop Science 191: 106-115

Xu Q, Paulsen A Q, Guikema J A \& Paulsen G M (1995). Functional and ultrastructural injury to photosynthesis in wheat by high temperature during maturation. Environmental and Experimental Botany 35: 43-54

Zamani M M, Nabipour M \& Meskarbashee M (2014). Stem water soluble carbohydrate remobilization in wheat under heat stress during the grain filling. International Journal of Agriculture \& Biology 16: 401-405

Zamani M M, Nabipour M \& Meskarbashee M (2015). Effect of heat stress during grain filling on photosynthesis and grain yield of bread wheat (Triticum aestivum L.) genotypes. Iranian Journal of Crop Sciences 17(1): 1-17

Zhao H, Dai T, Jing Q, Jiang D \& Cao W (2007). Leaf senescence and grain filling affected by post-anthesis high temperatures in two different wheat cultivars. Plant Growth Regulation 51: 149-158 